\title{
$\mathrm{CO}-\mathrm{H}_{2}$ 混合ガスからの遷移金属への 繊維状炭素の生成速度*
}

\author{
山下 昇 ${ }^{1}$ 新 堀 雄 - $^{2}$ \\ 土屋範 芳 $^{3}$ 千田 佶 $^{4}$
}

\section{The Formation Rate of Carbon Filaments on Transition Metals from $\mathrm{CO}-\mathrm{H}_{2}$ Gas Mixtures}

by Noboru YAMASHITA ${ }^{1}$, Yuichi NIIBORI ${ }^{2}$, Noriyoshi TSUCHIYA ${ }^{2}$ and Tadashi CHIDA ${ }^{2}$

1. Graduate Student, Tohoku University

2. Faculty of Engineering, Tohoku University, Aoba-ku, Sendai 980-77

The kinetic behavior of filamentous carbon formed on substrate of the transition metal ( $\mathrm{Fe}$, Co or $\mathrm{Ni}$ ) from $\mathrm{CO}-\mathrm{H}_{2}$ gas mixtures is investigated. The filamentous carbon holds carbide particle on its head point. Experiments for each metal are carried out in the range of $773 \sim 973 \mathrm{~K}$ with various molefraction of $\mathrm{CO}, Y_{\mathrm{CO}}$, in the gas mixtures. In the experimental results, the formation rates, $r$, for Fe-substrate are described by the following equation:

$$
r=\frac{k Y_{\mathrm{CO}} \sqrt{1-Y_{\mathrm{CO}}}}{\left(1+K Y_{\mathrm{CO}}\right)^{2}}, \quad 773 \mathrm{~K} \leqq T \leqq 873 \mathrm{~K},
$$

where $k$ is the rate constant, $K$ is the adsorption equilibrium constant and $T$ is temperature. The values of $k$ and $K$ give $92 \mathrm{~kJ} / \mathrm{mol}$ and $126 \mathrm{~kJ} / \mathrm{mol}$ as the apparent activation energy and the adsorption heat, respectively. This rate equation, however, is not applicable to the rates for $\mathrm{Co}$ - or Ni-substrate. Those data are explained by assuming the diffusion process of carbon adsorbed on the carbide particle as the determining step.

KEY WORDS : Filamentous Carbon, Formation Rate, Rate Determining Step, Transition Metal, Carbide Particle

\section{1. 緒言}

$\mathrm{Fe}, \mathrm{Co}, \mathrm{Ni}$ 等の遷移金属を触媒として C-H-O 系ガスから炭 素が析出する固気反応はよく知られている。また，金属表面上に 析出する炭素には太さ数 $10 \mathrm{~nm} \sim$ 数 $10 \mu \mathrm{m}$, 長さ数 $\mu \mathrm{m} \sim$ 数 $\mathrm{mm}$ の繊維状炭素が含まれている事例が知られており ${ }^{1)-5)}$, 新 たな気相成長炭素繊維の製造方法と考えられている。実用化され ている炭素繊維はポリアクリロニトリル（PAN）やピッチなど の有機繊維を原材料として製造されてきたが，用途の高度化と多 様化に対応する新たな性状を持つ炭素纎維が期待されている ${ }^{6)}$ 。 例えば, 電磁遮蔽材料, 複合導電材料, 半導体の放熱素子等の電 子産業への応用, 従来より利用されている吸着材の高性能化など が注目される778)。気相成長炭素繊維の特長は結晶性の良さと繊 維軸方向への結晶配向が極めて高いこと，中空構造を持つこと， 従来の繊維よりも繊維径が細いこと等が挙げられる年10)。また， 触媒として用いる遷移金属によって異なる繊維状炭素が得られる

\footnotetext{
* 1996 年 5 月 27 日受付 12 月 16 日受理

1. 学生会員 東北大学大学院工学研究科資源工学専攻 (現 侏)新潟鐵工所)

2. 正会員 工博 東北大学助教授 工学部量子エネルギー工学科

3. 正会員 工博 東北大学助教授 工学部地球工学科

4. 正会員 工博 東北大学教授 工学部地球工学科

〔著者連絡先〕 FAX 022-217-7900 (東北大·地球·千田研)

キーワード：繊維状炭素, 生成速度, 律速段階, 遷移金属, 炭化物粒子
}

可能性を有している。しかしながら瀻維状炭素の析出のメカニズ ムは未だ充分に解明されていないのが現状である。

本研究では C-H-O系ガスとして CO- $\mathrm{H}_{2}$ 混合ガスを使用し, 基 板として Fe, Co, Ni を用いた場合における繊維状炭素の析出 挙動について速度論的な見地から検討を行った。

\section{2. 実 験 方 法}

\section{$2 \cdot 1$ 試料および実験装置}

実験装置の概略図をFig. 1 に示す。熱天秤は真空理工(株)製 自記式示差熱天秤 TGD-5000RH-Sを使用した。熱天秤の炉内の 試料室の直径は $26 \mathrm{~mm}$, 長さは $46 \mathrm{~mm}$ であり, 試料はこの中に アルミナ製の試料台を用いて設置する。試料重量の変化はデー夕 ロガー・サーモダック Eにより数值デー夕に変換し RS232C を 介してパーソナルコンピュータPC9801に取り込みフロッピーディ スクに記録した。

実験に用いた試料は $\mathrm{Fe}$ (日本電球工業(株), 純度 $99.5 \%$ ), Co ((株)ニラコ, 純度 $99.9 \%$ ), Ni (日本電球工業(株), 純度 $99.7 \%$ ）の金属基板である。いずれの基板も $0.3 \sim 0.5 \mu$ の微細空 隙をもつ。それぞれの金属基板は $15 \mathrm{~mm} \times 15 \mathrm{~mm} \times 0.1 \mathrm{~mm} の$ 大きさに切断し実験に供した。反応ガスは, $\mathrm{CO}, \mathrm{H}_{2}$ の市販のボ ンベガスを所定の流量比で混合して用いた。各ガスはオーバーフ ローによって圧力を一定にし, シリカゲルならびに五酸化リンを 

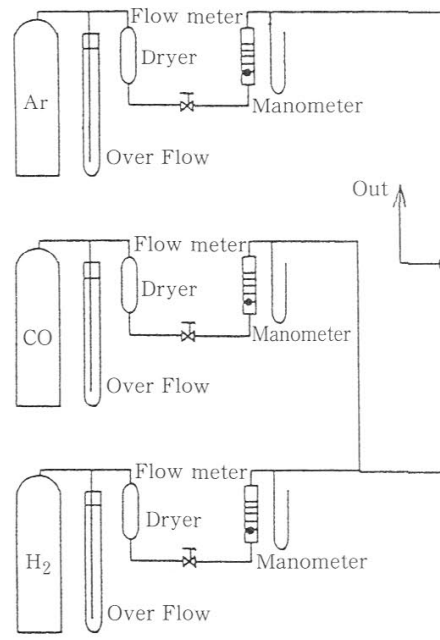

Fig. 1 Schematic diagram of the experimental apparatus.

充填した乾燥塔を通すことにより，ガス中の湿気を除去した。

\section{$2 \cdot 2$ 実験方法}

本研究における炭素析出実験では温度およびガス混合比を変え て実験を行った。基板をアセトン中で30分間超音波洗浄すること により基板表面を脱脂し，炉内の試料台へ垂直に設置した。昇温 した際に金属試料が酸化しないように炉内へArガスを 2 時間流 し大気と充分に置換した後, $\operatorname{Ar}$ ガス中に拀いて $30 \mathrm{~K} / \mathrm{min}$ で昇 温する。目標温度に達したところで試料表面の酸化膜を還元する ために $\mathrm{Ar}$ ガスを $\mathrm{H}_{2}$ ガスに切り替えて10 分間流した後, 再び $\mathrm{Ar}$ ガスによる置換を 5 分間行った。 $\mathrm{CO}-\mathrm{H}_{2}$ 混合ガスを $0.5 \sim 2$ 時 間流し炭素析出反応実験を開始する。反応中の炭素析出量は試料 重量の増加量として計測した。 $\mathrm{CO}-\mathrm{H}_{2}$ 混合ガスの流量は $600 \mathrm{ml}$ / min とし, 反応温度は 773 9 9 $\mathrm{K}$ の範井で行った。反応終了 後は $\mathrm{Ar}$ ガス中で自然冷却して降温する。

\section{3. 実験結果および考察}

\section{$3 \cdot 1$ 析出炭素}

$\mathrm{CO}$ のモル分率 $Y_{\mathrm{CO}}$ が 0.6 の場合に扔いて反応温度が $873 \mathrm{~K} の$ $\mathrm{Fe}, \mathrm{Co}, \mathrm{Ni}$ それぞれの炭素析出重量の経時変化をFig. 2(a)に 示す。Feを用いた時の析出量は Co, Ni と比較して大きいこと が分かる。また, Fig. 2(b)に Fe 基板を用いた $873 \mathrm{~K} の$ 場合の各 $Y_{\mathrm{CO}}$ に㧍ける析出重量の経時変化を, Fig. 2(c)に同じく Fe 基板 を用い $Y_{\mathrm{CO}}$ が 0.6 の場合の各反応温度における析出重量の経時 変化を示す。これらの図より, 重量変化は反応条件によっても大 きく異なり，その経時変化は複雑な曲線となることが分かる。
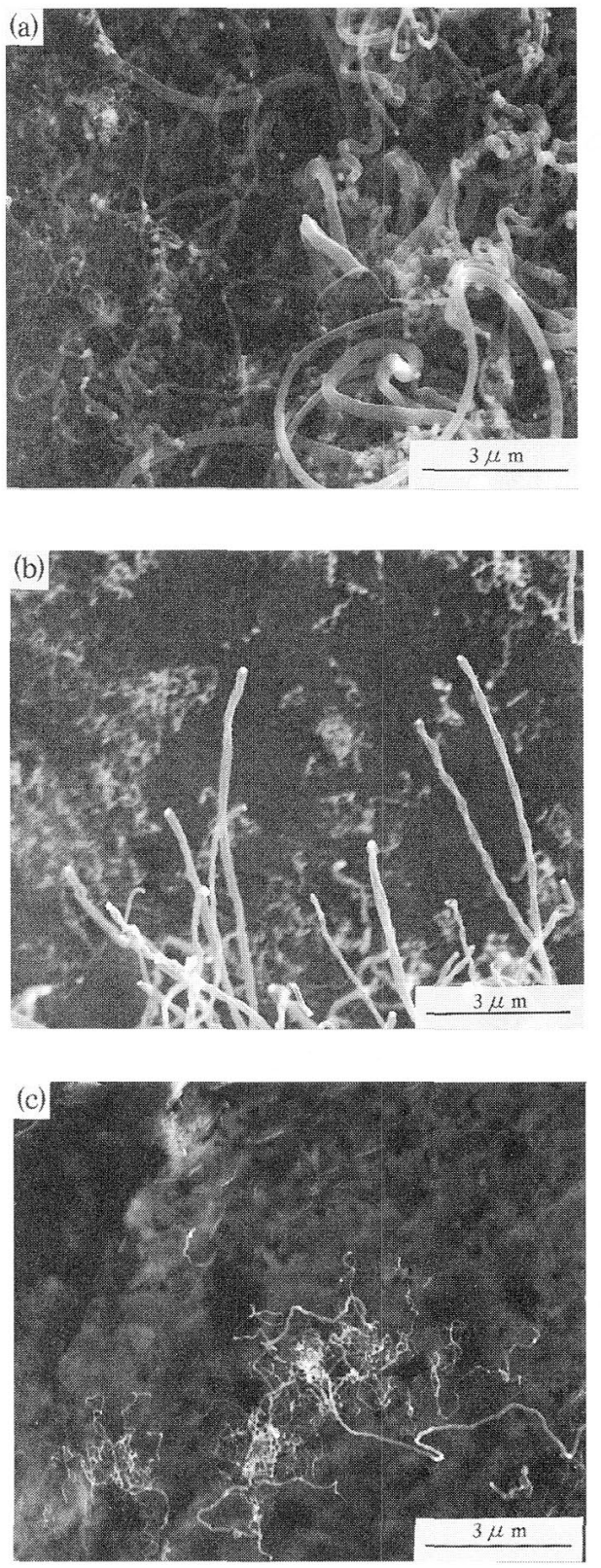

Fig. 3 SEM micrographs of carbon deposits from $\mathrm{CO}-\mathrm{H}_{2}$ at $873 \mathrm{~K}$ and $Y_{\mathrm{CO}}=0.6$ ( $Y_{\mathrm{CO}}$; the mole-fraction of $\mathrm{CO}$ ) on (a)iron, (b) cobalt and (c) nickel substrates.

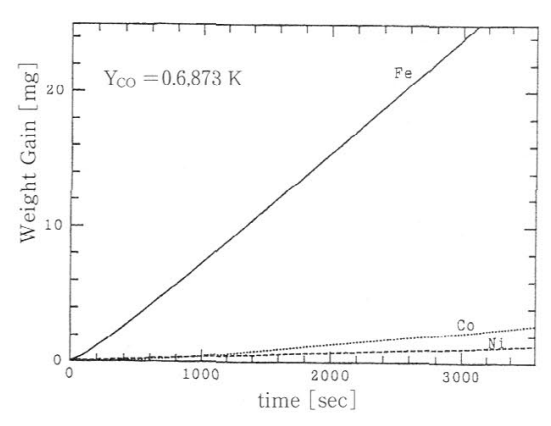

(a)

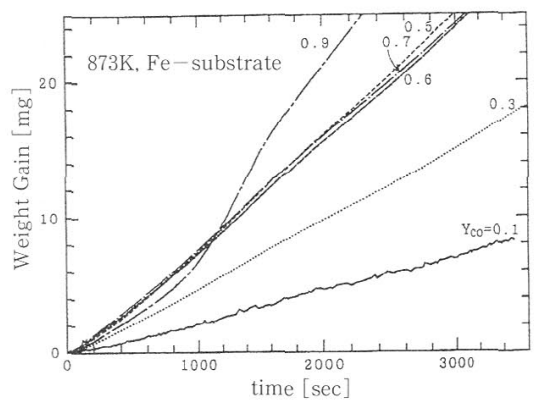

(b)

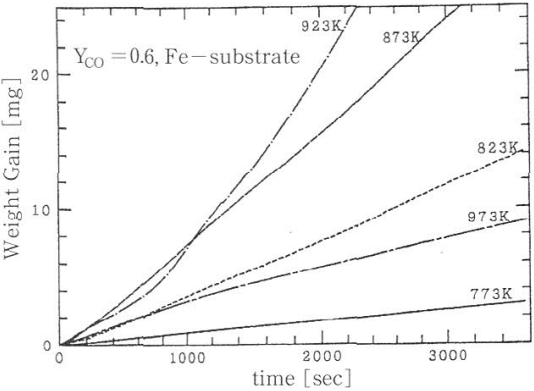

(c)

Fig. 2 The weight gains of the carbon deposition on the substrates from CO- $\mathrm{H}_{2}$ gas mixtures ( (a)the effects of substrate at $873 \mathrm{~K}$ and $Y_{\mathrm{CO}}=0.6$, where $Y_{\mathrm{CO}}$ is the mole-fraction of $\mathrm{CO}$, (b)the effects of $Y_{\mathrm{CO}}$ at $873 \mathrm{~K}$ for Fe substrate, (c) the effects of temperature at $Y_{\mathrm{CO}}=0.6$ for Fe substrate). 
(a)

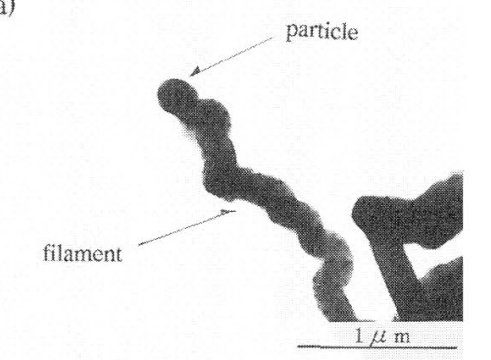

(b)

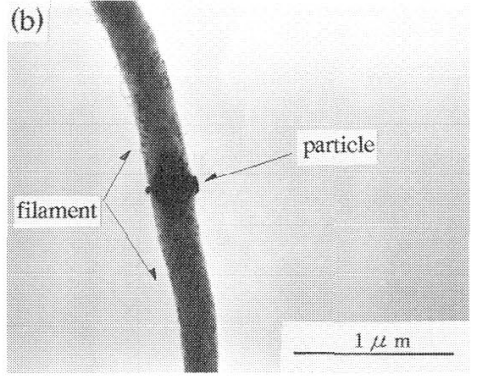

Fig. 4 TEM micrographs of (a) the head point of the carbon filament and (b)carbon filaments including the lozenge particle from $\mathrm{CO}-\mathrm{H}_{2}$ on iron substrate ( 873 $\mathrm{K}, Y_{\mathrm{CO}}=0.4$ )

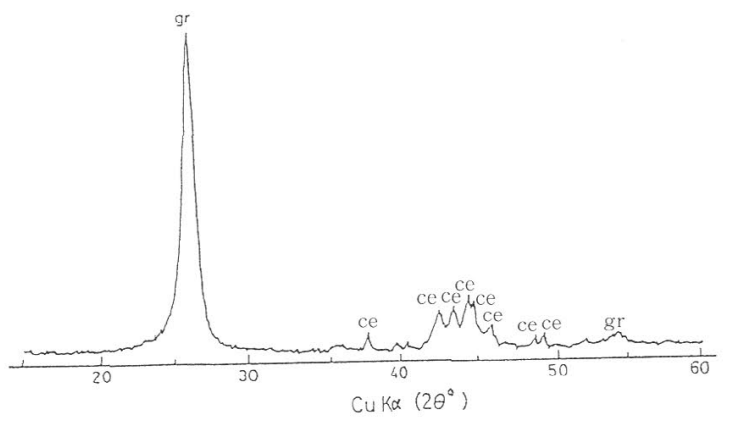

Fig. 5 XRD pattern of the carbon deposit on iron substrate $\left(873 \mathrm{~K}, Y_{\mathrm{CO}}=0.3\right.$, gr: graphite, ce cementite).

Fig. 3 に $Y_{\mathrm{CO}}$ が 0.6 , 温度 $873 \mathrm{~K}$ において析出した瀻維状炭素の 走查電子顕微鏡像走す。Fig. 3(a) は Fe 基板老用いた場合で, 析出した䄉維状炭素の大きさは太いもので約 $0.3 \mu \mathrm{m}$, 長さ約十 数 $\mu \mathrm{m}$ ，并の形状は曲がりく极っているものが多い。Fig. 3(b)は Co 基板を用いた場合で, 析山した繊維状岑素のほとんどが，太 さ約 $0.2 \mu \mathrm{m}$, 長さは $10 \mu \mathrm{m}$ 以下である。Fig. 3(c) は Ni の場合 であり, 太さ約 $0.1 \mu \mathrm{m}$ 以下, 長さは $10 \mu \mathrm{m}$ 以下である。Fig. 4 (a)にFe老基板とし，反灾温度が $873 \mathrm{~K} 、 Y_{\mathrm{CO}}$ が 0.4 の条件下で 析出した瀻維状炭素の透過電子顕微鏡像圭示す。この㵶維状炭素 の太さは約 $180 \mathrm{~nm}$ であり, 複雑にねじれながら成長しており必 ずしも直進性はよくないが，写真から確認される見かけの長さは 約 $2 \mu \mathrm{m}$ である。瀻維状岑素の先端には電子線を透過しにくい精 子が存在する。さらに, Fig. 1(b)には, 瀻維状炭素の中途に電 子線老透過しにくい菱形の粒子が確認できる。Fig. 5 に Fe 基板 上で, $873 \mathrm{~K}, Y_{\mathrm{CO}}=0.3$ の場合に析出した䋐維状炭素の粉末 $\mathrm{X}$ 線回折結果を示す。グラファイトの回折線の他, セメンタイト $\left(\mathrm{Fe}_{3} \mathrm{C}\right)$ の回折線が確認でさる。この結果と透過電子顕微鏡観察 結果を合わせると, 纎維状炭素の先端および中途に観察される粒 子は，七メンタイトであると判断される。

Ni 拉よびCo t基板として用いた場合には, 析出炭素量が Fe に比して著しく少ないことから, 通常の粉末 X 線回折では瀻維
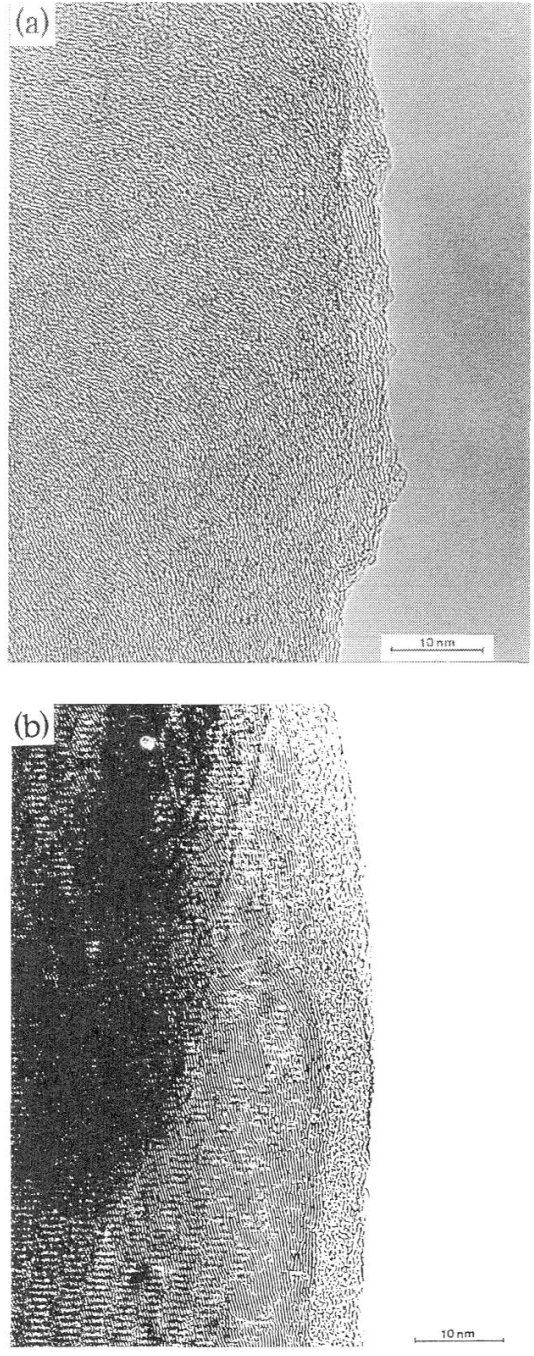

Fig. 6 (002) lattice image of carbon filament from $\mathrm{CO}-\mathrm{H}_{2}$ on iron substrate ( (a) $773 \mathrm{~K}, Y_{\mathrm{CO}}=0.7$, (b) $873 \mathrm{~K}, Y_{\mathrm{CO}}=0.7$ ).

状炭素と共存する微粒子を同定することはできなかった。しかし ながら, 透過電子顕微鏡による制限視野電子線回折から $\mathrm{Ni}$ 基板 の場合の瀻維状炭素の先端や中途にある粒子は $\mathrm{Ni}_{3} \mathrm{C}, \mathrm{CO}$ 基板を 用いた場合には $\mathrm{CO}_{3} \mathrm{C}$ であることを確認した。

$\mathrm{Fe}$ 基板で $Y_{\mathrm{CO}}=0.7$ の場合の $773 \mathrm{~K}, 873 \mathrm{~K}$ の条件下で析出 した瀻維状炭素の（002）格子像をそれぞれFig. 6(a)，Fig. 6(b) に示す。写真の上下う何が㵶維状炭素の伸長方向である。773 K の場合の(002) 格子は伸長方向に対して弱い定方位性で配向し, 規則的に積層する炭素網面はほとんどが 10 層以下である。これ に対して $873 \mathrm{~K}$ の場合は, 伸長方向に対して強い定方位性を示 し, かつ炭素網面の積層数も20３0層となり, 非常に規則的に 配列している。また，773 K 抢よび $873 \mathrm{~K}$ のいずれの場合におい ても, 繊維状炭素の表層の $5 \mathrm{~nm}$ 程度は, 炭素網面の積層数が 2３層しかなく, かつ（002）格子も内部に比べて定方位性が弱 い。この配向が不規則な部分の炭素析出過程は内部とは異なると 推察されるが, 詳細な検討は今後の課題である。

\section{$3 \cdot 2 \mathrm{Fe}$ 基板上への析出速度式}

炭素析出反応への反応温度およびガス混合比の影響を検討する ために経洔変化から析出速度を求め評洒する。ここでは実験によ り得られた炭素の析出重量の経時変化量小自乗法により３次関 数で近似した。近似することにより得られた関数から, 孷素が一 


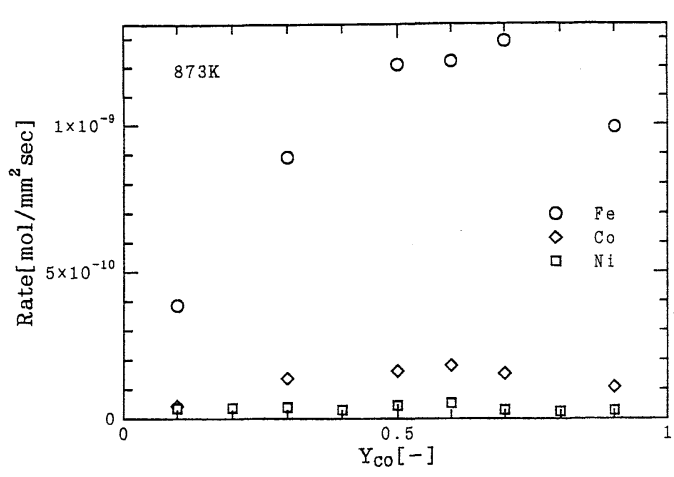

Fig. 7 Relationship between the deposition rate and $Y_{\mathrm{CO}}$ $(873 \mathrm{~K})$.

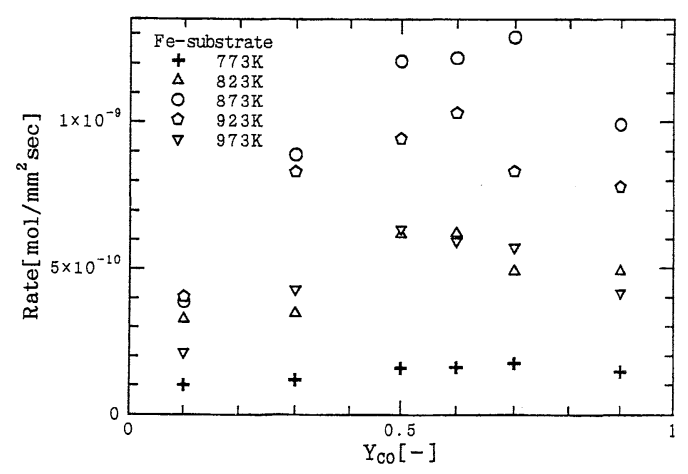

Fig. 8 Temperature dependence of the deposition rates against $Y_{\mathrm{CO}}$ for iron substrate.

定量析出した時点における微分値を求め, さらに基板の表面積 $\left[\mathrm{mm}^{2}\right]$ で割り, その值を炭素析出速度とした。Fig. 7 に反応温 度が $873 \mathrm{~K}$ の場合の $Y_{\mathrm{CO}}$ と析出速度 $r$ との関係を示す。実験開 始後数十秒後の基板（Fe）の表面を SEM 観察したところ, ごく 初期では粒子状炭素が観察され, 瀻維状のものは観察されなかっ た。そこで, 本研究では炭素が単位面積当たり $1.0 \times 10^{-7} \mathrm{~mol}$ 析出した時点（Fig. 2 の縦軸では約 $0.5 \mathrm{mg}$ に相当）での速度を 用いた。Fig.7より Fe を用いたときの析出速度は $\mathrm{Co}, \mathrm{Ni}$ と比 較して大きいことが分かる。また $\mathrm{Fe}$ の場合, 析出速度は $Y_{\mathrm{CO}}$ に大きく依存している。Fig. 8 は Fe を用いたときの各温度条件 における $Y_{\mathrm{CO}}$ と析出速度 $r$ との関係を示したものである。反応 温度が $873 \mathrm{~K}$ の場合にどの CO モル分率においても析出速度は大 きくなる。また, 各温度条件において $Y_{\mathrm{CO}}$ が 0.5 付近で析出速 度が大きくなる傾向が見られる。これらの析出速度から, 基板と して Fe を用いた時の炭素析出反応を表す速度式を以下に導く。 本研究における炭素析出は総括反応として式(1)により進行す る。

$$
\mathrm{CO}+\mathrm{H}_{2}=\mathrm{C}+\mathrm{H}_{2} \mathrm{O}
$$

Fig. 4(a)，（b)から明らかなように, 繊維状炭素の先端または中 途には金属カーバイド粒子が存在し, また粒子直径と繊維上炭素 の直径がほぼ同様であることから， Fe（またはセメンタイト） 表面への吸着が炭素の析出反応に本質的な役割を果たしていると 考えることができる。ここでの吸着は Langmuir 型を仮定し， 反応は以下に示す素反応により進行すると考える。

$$
\begin{aligned}
& \mathrm{CO}+\sigma=\mathrm{C}+\mathrm{O} \sigma \\
& \mathrm{H}_{2}+2 \sigma=2 \mathrm{H} \sigma \\
& \mathrm{H} \sigma+\mathrm{O} \sigma=\mathrm{OH} \sigma+ \\
& \mathrm{OH} \sigma+\mathrm{H} \sigma=\mathrm{H}_{2} \mathrm{O}+2 \sigma
\end{aligned}
$$

ここで $\sigma$ は Fe 表面の吸着座を表す。式(4)の素反応が律速段階
であると仮定すると，反応速度 $r$ は，

$$
r=k_{1} \theta_{\mathrm{H}} \theta_{\mathrm{O}}-k_{2} \theta_{\mathrm{OH}} \theta
$$

となる。ここで， $k_{1}, k_{2}$ はそれぞれ式(4)の素反応の正反応およ び逆反応の反応速度定数を表す。 $\theta_{\mathrm{i}}$ は全吸着座に対する $\mathrm{i}$ 成分 の吸着率を示している。式(2)から式(5)より以下の式が求められ る。

$$
\begin{aligned}
& \theta_{\mathrm{O}}=K_{1} Y_{\mathrm{CO}} \theta \\
& \theta_{\mathrm{H}}=\sqrt{K_{2} Y_{\mathrm{H}_{2}}} \theta \\
& \theta_{\mathrm{OH}}=\frac{Y_{\mathrm{H}_{2} \mathrm{O}} \theta_{2}}{\theta_{\mathrm{H}} K_{3}}=\frac{Y_{\mathrm{H}_{2} \mathrm{O}} \theta}{\sqrt{Y_{\mathrm{H}_{2}}} K_{3} \sqrt{K_{2}}}
\end{aligned}
$$

ここで $\theta$ は何も吸着していない吸着座の割合, $K_{1}, K_{2}, K_{3}$ はそ れぞれ式(2)，(3)，(5)で表される素反応の平衡定数である。ま た,

$$
\theta+\theta_{\mathrm{H}}+\theta_{\mathrm{O}}+\theta_{\mathrm{OH}}=1
$$

であり, 解離吸着する酸素量よりも他の吸着量が極めて小さいと 仮定 $\left(\theta_{\mathrm{H}} \ll \theta_{\mathrm{O}}, \quad \theta_{\mathrm{OH}} \ll \theta_{\mathrm{O}}\right)$ すると, $\theta$ は

$$
\theta=\frac{1}{1+K_{1} Y_{\mathrm{CO}}}
$$

となる。

以上より反応速度 $r$ は, 次式となる。

$$
r=\frac{k Y_{\mathrm{CO}} \sqrt{Y_{\mathrm{H}_{2}}}-\frac{Y_{\mathrm{H}_{2} \mathrm{O}}}{\sqrt{Y_{\mathrm{H}_{2}}} K_{\mathrm{e}}}}{\left(1+K_{1} Y_{\mathrm{CO}}\right)^{2}}
$$

ここで $k, K$, および $K_{\mathrm{e}}$ は

$$
\begin{aligned}
& k=k_{1} K_{1} \sqrt{K_{2}} \\
& K=K_{1} \\
& K_{\mathrm{e}}=\frac{K_{3} \sqrt{K_{2}}}{k_{2}}
\end{aligned}
$$

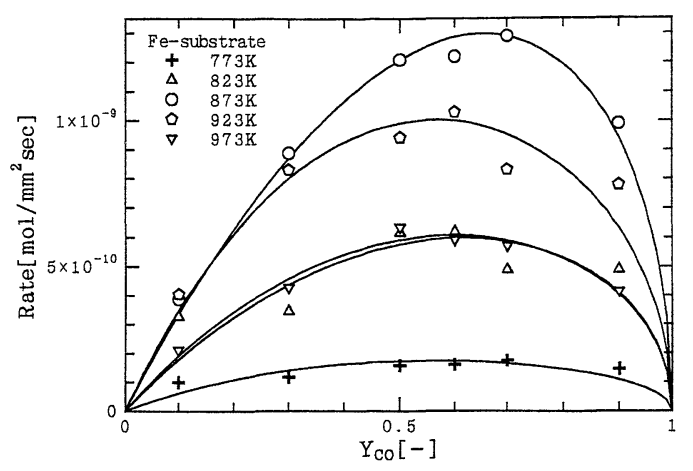

Fig. 9 Calculated results of eq. (14) in the case of iron substrate (the fitting parameters were optimized by the non-linear least square method.).

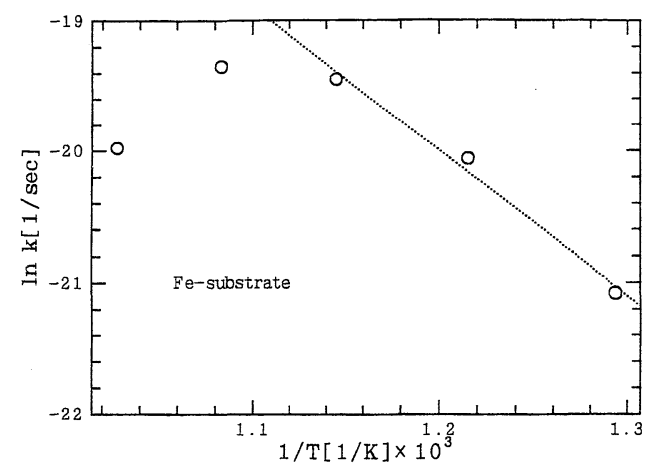

Fig. 10 Arrhenius plot of the rate constant for iron substrate $(k$ : the rate constant $[1 / \mathrm{sec}], T:$ temperature $[\mathrm{K}])$. 


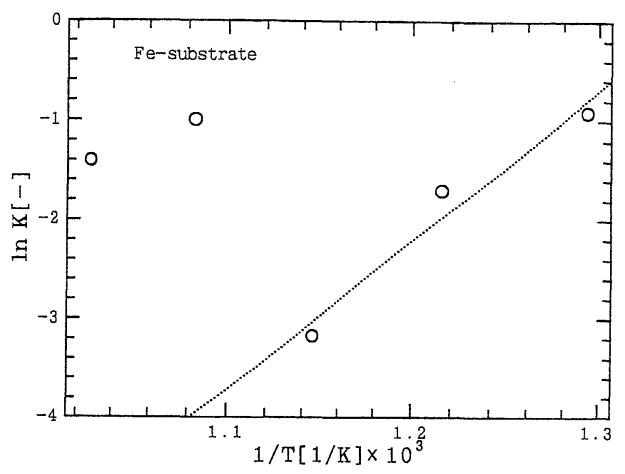

Fig. 11 Relationship between temperature, $T[\mathrm{~K}]$, and the adsorption equilibrium constant, $K[-]$, for iron substrate.

である。反応初期に抢ける水の発生量は極めて少ないので $\mathrm{H}_{2} \mathrm{O}$ のモル分率を 0 とみなし $\left(Y_{\mathrm{H}_{2}}=1-Y_{\mathrm{CO}}\right)$, 以下の速度式を得 る。

$$
r=\frac{k Y_{\mathrm{CO}} \sqrt{1-Y_{\mathrm{CO}}}}{\left(1+K Y_{\mathrm{CO}}\right)^{2}}
$$

式(14)に表される速度式のパラメー夕である反応速度定数 $k$, 吸 着平衡定数 $K$ は，実験值を最もよく表す値を非線形最小自乗法 により求めた。Fig. 9 中の実線は $1.0 \times 10^{-7} \mathrm{~mol} / \mathrm{mm}^{2}$ の炭素 が析出した時点における $\mathrm{Fe}$ を基板とした際の反応速度の実験結 果に式(14)をフィッティングした結果を示したものである。いず れの温度においても速度式の曲線は実験值をよく表している。 Fig. 10 はFig. 9 において得られた反応速度定数 $k$ の值をアーレ ニウスプロットしたものである。 $k$ と $1 / T$ の間には直線関係が みられず，実験温度範囲全体にわたりアーレニウスの式は成立し ていない。これは $873 \mathrm{~K}$ の温度を境とし，それより低温側と高 温側で反応機構に違いがあることを示している。試みに $773 \sim 873 \mathrm{~K}$ の範囲で直線近似した結果が図中の直線である。直 線の傾きからみかけの活性化エネルギー $E_{\mathrm{a}}$ を求めたところ 92 $\mathrm{kJ} / \mathrm{mol}$ であった。この值は十分大きなもので反応律速とみなし てもよいものである。Fig. 11 はFig. 9 において得られた吸着平 衡定数 $K$ の值と温度との関係を示したものである。 $k$ の場合と 同様に $773 \sim 873 \mathrm{~K}$ の $K$ の值を直線近似し，その傾きから $\mathrm{CO} の$ $\mathrm{Fe}$ 基板上への吸着熱を求めたところ $126 \mathrm{~kJ} / \mathrm{mol}$ であった。こ れは文献值 ${ }^{11)}$ による值 $120 \sim 140 \mathrm{~kJ} / \mathrm{mol}$ とほほ一致している。 このことから基板として Fe を用いた場合には $873 \mathrm{~K}$ 以下におい て式(14)により炭素の析出速度を表し得ることが分かる。

以上の議論は $873 \mathrm{~K}$ 以上で成立しない。923 K, $973 \mathrm{~K}$ に抒い て炭素の析出速度が $873 \mathrm{~K}$ のときよりも遅く, Fig. 10 および Fig. 11 における $k, K$ の值がそれぞれ 773〜873 K の延長線上に ない理由として炭素析出反応に抒ける逆反応の影響が挙げられる。 式(1)の炭素析出反応は発熱反応であり, その平衡定数は温度が 高いほど小さくなる。また，上述の解析において無視した生成物 の $\mathrm{H}_{2} \mathrm{O}$ が無視できない量発生し, 逆反応で炭素と反応してしま うため析出速度が小さくなるとも考えられる。

\section{$3 \cdot 3$ Co および $\mathrm{Ni}$ 基板上への析出速度式}

$\mathrm{Co}, \mathrm{Ni} に つ い て も \mathrm{Fe}$ 同様に, 実験值を式(14)を用いて整理 することを試みた。Co，Ni を用いたときのみかけの活性化工ネ ルギーの值はFig. 12 に示すアーレニウスプロットより，それぞ れ $29,43 \mathrm{~kJ} / \mathrm{mol}$ であり，ともに Fe を用いたときと比較すると 小さな值であった。また, $\mathrm{CO}$ の各基板への吸着熱の值は Fig. 13 よりそれぞれ $-43,-56 \mathrm{~kJ} / \mathrm{mol}$ であり文献值 ${ }^{12)}$ とは大きく 異なる。これらの結果は基板として Co, Ni を用いた場合, 炭素

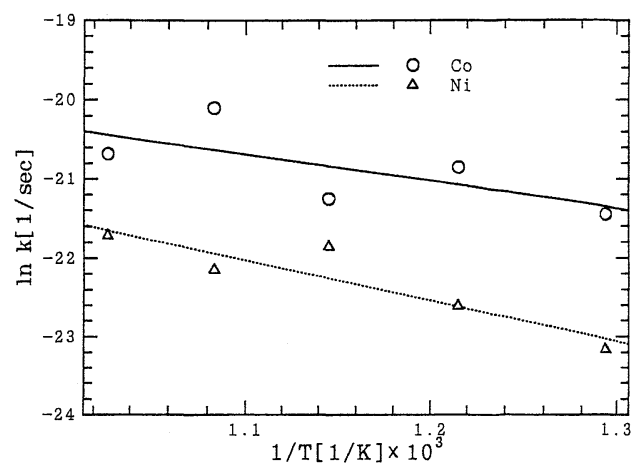

Fig. 12 Arrhenius plot of the rate constant for cobalt and nickel substrate $(k$ : the rate constant $[1 / \mathrm{sec}], T$ temperature $[\mathrm{K}])$.

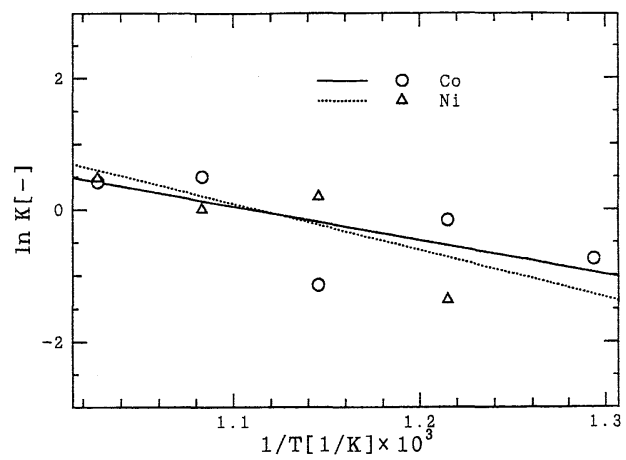

Fig. 13 Relationship between temperature, $T[\mathrm{~K}]$, and the adsorption equilibrium constant, $K[-]$, for cobalt and nickel substrate.

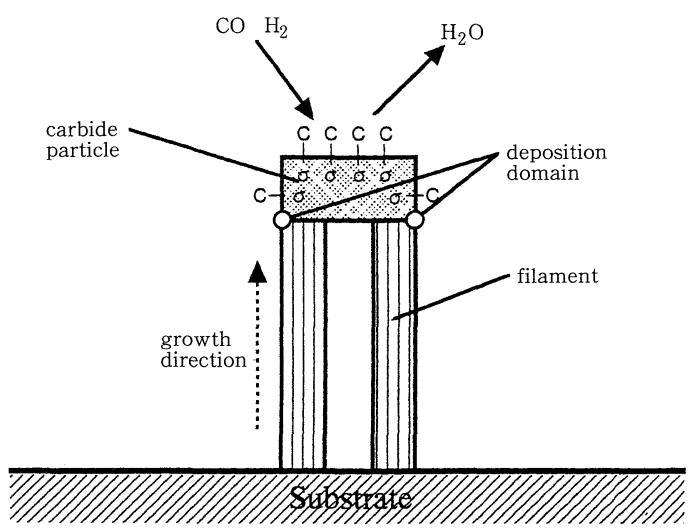

Fig. 14 Illustration of the growth of filamentous carbon.

析出反応の速度を表す速度式として式(14)を適用することはでき ず，Co，Ni を用いた炭素析出反応の律速段階は Fe を用いた場 合とは異なることを意味する。

式(14)を基に得られたみかけの活性化エネルギーは Co, Ni 用いたとき, いずれも小さな值となったことから, これらの炭素 析出反応は何らかの拡散過程によって支配されていると考えられ る。しかしながら, いずれの拡散過程が律速かは明確ではないた め, 本研究では, 試みに Co, Ni を用いた場合の炭素析出反応の 律速段階としてカーバイド粒子表面上における炭素の拡散過程を 仮定する。その概念図をFig. 14 に示す。ここでは, 中空構造を もつ繊維の断面を, 繊維状炭素の先端に存在するカーバイドの粒 子と併せて模式的に表している。カーバイド表面上では，まず， 反応ガスの吸着, 水蒸気の発生, 炭素の吸着座との結合（図中, 


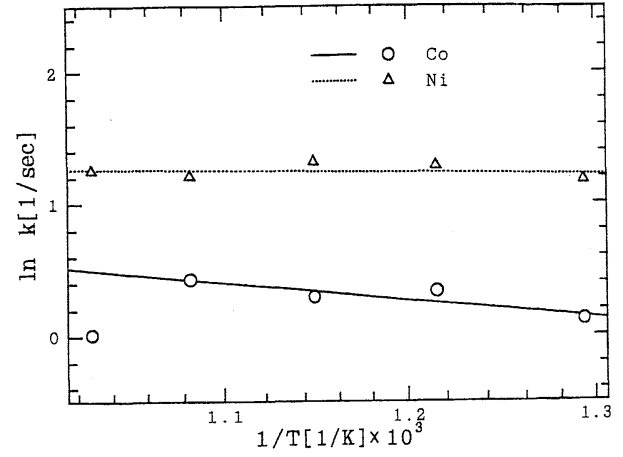

Fig. 15 Arrhenius plot of the rate constant for cobalt and nickel substrate ( $k$ : the rate constant $[1 / \mathrm{sec}], T$ : temperature $[K])$.

$\sigma-\mathrm{C})$, その固体炭素への拡散があり，そして，吸着している 炭素が，炭素の集まり（繊維状炭素）に取り込まれることにより 瀻維状炭素はさらに成長すると考える。この一連の過程において 炭素の吸着率が小さい領域, すなわち固体炭素への拡散を律速と 仮定する。この場合の速度式は以下のように導くことができる。 いま,

$\mathrm{H}_{2}+\mathrm{CO}+\sigma=\mathrm{H}_{2} \mathrm{O}+\mathrm{C} \sigma$

$\mathrm{C} \sigma=\mathrm{C}+\sigma$

として，式(15)を平衡とみなすとき，

$$
K=\frac{\theta_{\mathrm{C}} Y_{\mathrm{H}_{2} \mathrm{O}}}{Y_{\mathrm{CO}} Y_{\mathrm{H}_{2}} \theta}
$$

が成立する。ここで $\theta_{\mathrm{C}}$ は炭素の吸着率を表す。一方, 炭素の吸 着率が大きい領域 (吸着率 $\theta_{\mathrm{C}}$ ) と固体炭素表面近傍（炭素吸着 率 0）との間の拡散が律速とすれば, 拡散速度は吸着率の差すな わちに $\theta_{\mathrm{C}}$ に比例すると考えられるから，式(16)の右への速度は みかけ上の一次反応として,

$$
r=k \theta_{\mathrm{C}}
$$

と表すことができる。また，

$$
\theta+\theta_{\mathrm{C}}=\theta_{\mathrm{m}}(=\text { 一定 })
$$

$$
\text { とすると式(17)～式(19)より }
$$

$$
r=\frac{k K \theta_{\mathrm{m}} Y_{\mathrm{CO}} Y_{\mathrm{H}_{2}}}{Y_{\mathrm{H}_{2} \mathrm{O}}+K Y_{\mathrm{CO}} Y_{\mathrm{H}_{2}}}
$$

となる。カーバイト表面近傍において水蒸気は速やかに周囲に移 動すると考えると $Y_{\mathrm{H}_{2} \mathrm{O}}=0$ とみなせ, 式(20)は

$$
r=k \theta_{\mathrm{m}}
$$

となる。すなわち, ガス混合比に依存しない速度式が得られる。 式(21)の $k$ を各温度条件に打ける $1.0 \times 10^{-7} \mathrm{~mol} / \mathrm{mm}^{2}$ 析出時 の反応速度の平均值として, Co, Ni を用いた場合の炭素析出反 応の活性化エネルギーを求めたところ, それぞれ $13 \mathrm{~kJ} / \mathrm{mol}$ 扔 よび $1.5 \mathrm{~kJ} / \mathrm{mol}$ であった。これらのアーレニウスプロットを
Fig. 15 に示す。一般に拡散律速である場合の活性化エネルギー の值は反応律速である場合の值より小さいことから, この值は炭 素の拡散過程を律速段階とした本モデルの仮定に矛盾しない。

\section{4. 結}

本研究は $\mathrm{CO}-\mathrm{H}_{2}$ 混合気体から $\mathrm{Fe}, \mathrm{Co}, \mathrm{Ni}$ 基板上への繊維状 炭素の析出挙動について研究を行ったところ以下のようなことが 明らかになった。

$\mathrm{Fe}$ を基板として用いた場合には, 直径約 $0.3 \mathrm{~mm}$, 長さ十数 $\mathrm{mm}$, Co を基板として用いた場合には直径 $0.22 \mathrm{~mm}$, 長さ 10 $\mathrm{mm}$ 以下, $\mathrm{Ni}$ では直径 $0.1 \mathrm{~mm}$, 長さ $10 \mathrm{~mm}$ 以下の繊維状炭素 が析出した。いずれの遷移金属を基板として用いた場合でも, 繊 維状炭素の先端や中途には, 繊維状炭素の直径とほほ同様な大き さの金属カーバイド粒子が存在している。これらの観察結果をも とに, $\mathrm{CO}-\mathrm{H}_{2}$ 混合気体から $\mathrm{Fe}$ 基板上に扔ける炭素の析出は, 773 $873 \mathrm{~K}$ の温度範囲において表面における反応が律速段階で あり, 速度式である式(14)を提案した。実験により得られた 1.0 $\times 10^{-7} \mathrm{~mol} / \mathrm{mm}^{2}$ の炭素析出時の速度を速度式により整理した ところ, みかけの活性化エネルギー, $\mathrm{CO}$ の基板への吸着熱の值 はそれぞれ $92 \mathrm{~kJ} / \mathrm{mol}$ および $126 \mathrm{~kJ} / \mathrm{mol}$ であった。Co, Ni を 基板として用いた場合，同じ実験条件における $\mathrm{Fe}$ 基板を用いた 時の炭素析出反応の律速段階とは異なり, 炭素の表面拡散が律速 段階と仮定することによりほぼ実験值を説明できる。

謝辞本研究を進める上でご協力頂いた東北大学大学院 高 橋朋之氏（現 ソニー(侏) ならびに松井憲夫氏（現 三協アルミ ニウム(侏)）に記して謝意を表する。

\section{引用 文 献}

1) De Bokx, P. K., Kook, A. J. H. M., Boellaard, E., Klop, W. and Geus, J. W. : J. Catal., Vol. 96, p. 454-467, (1985)

2) Kook, A. J. H. M., De Bokx, P. K., Boellaard, E., Klop, W. and Geus, J. W. : J. Catal., Vol. 96 , p. $468-480$, (1985)

3) Jackson, P. R. S., Trimn, D. L. and Young, D. J. : J. Mater. Scis., Vol. 21, p. $3125-3134$, (1986)

4) Alstrup, I. : J. Catal., Vol. 109, p. 241-251, (1988)

5) Nolan, P. E., Lynch, D. C. and Cutler, A. H. : Carbon, Vol. 32, p. 477483, (1994)

6）藤木良規：資源と素材, Vol. 112, p. 199-206, (1996)

7）稲垣道夫：ニューカーボン, p. 100-108, (1990), 冬樹社

8）本田英昌・小林和夫：ハイテク炭素材料, p. 227-229, (1987), 工業調査会

9）稲垣道夫：炭素材料工学 (1985), 日刊工業新聞社

10) Figueiredo, J. L., Bernardo, C. A., Baker, R. T. K. and Huttinger, K. J. : "Carbon Fibers Filaments and Composites" (1989) Kluwer Academic Publishers

11）葉煦雲 ·沼田博雄 ·春山志郎：日本金属学会誌, Vol. 7, p. 529-535, (1985)

12）小間 篤·八木克道·塚田 捷·青野正和：表面物性工学ハンドブック，p 543 ，(1987), 丸善 